\title{
Yoğun bakımda yapılacak bir şeyi kalmayan kanserli terminal dönem hastalara insanca bakım önerisi
}

\author{
Suggestions on providing humanistic health care for terminally ill cancer \\ patients in the intensive care unit
}

\author{
Halil Berkay Uzuncu, Hüsniye Buyruk, Ezgi Alnak, Gülay Yıldırım* \\ Tıp Fakültesi öğrencileri (H. B. Uzuncu, H. Buyruk, E. Alnak), Tıp Tarihi ve Etik Anabilim Dalı \\ (Yrd. Doç. Dr. Gülay Yıldırım), Cumhuriyet Üniversitesi Tıp Fakültesi, TR-58140 Sivas
}

\begin{abstract}
Özet
Yoğun bakım ünitelerimizde ekip ve ekipman sorunlarının sıkça yaşanması nedeni ile hekimler sağlık kaynaklarının dağıtımıyla ilgili birçok etik problemle karşılaşmaktadır. Bir yandan da terminal dönem hastalarına tedavi ve bakımın multidisipliner ekip anlayışı ile verilebileceği, hasta bu bakımı alırken, yakınları ile beraber olabileceği ortamların yaratılmasının hem hasta hem de yakınları açısından yararlı olacağı düşünülmektedir. Bu bağlamda makalemizde kanserli terminal dönem hastalarının yoğun bakım sürecini yaşadıktan sonra yapılacak bir şeyin kalmadığ noktasında, insan onuruna yakışır şekilde bakım ve tedavisinin devam edebilmesi ve bu süreci yaşayan hasta ve yakınlarının gereksinimlerinin karşılanabileceği hospislerin Türkiye'de kurulmasının önemi vurgulanmıştır.
\end{abstract}

Anahtar sözcükler: Hospis, terminal dönem, yoğun bakım

\begin{abstract}
Physicians face many ethical problems on the distribution of health resources due to team and equipment problems frequently seen in intensive care units. On the other hand, it is considered that treatment and care can be provided for terminal patients with the multidisciplinary team approach, and that creating environments where patients stay together with the relatives while receiving this care would be useful both for patients and for their relatives. In this context, it is stressed that establishing hospices in Turkey where terminal cancer patients who have completed the intensive care process and for whom nothing else can be done continue to receive their treatment and the patients' and their relatives' needs are met in a manner worthy of human dignity.
\end{abstract}

Keywords: Hospice, terminal period, intensive care

Geliş tarihi/Received: 07 Ekim 2011; Kabul tarihi/Accepted: 04 Nisan 2012

*iletişim adresi:

Dr. Gülay Yıldırım, Tıp Tarihi ve Etik Anabilim Dalı, Cumhuriyet Üniversitesi Tıp Fakültesi, TR58140 Sivas. E-posta: gyildirimg@gmail.com

Bu çalışma 2011 yılında Gazi Üniversitesi Tıp Fakültesi, Tıp Etiği ve Tarihi Anabilim Dalı tarafindan düzenlenen 2. Uluslararası Katılımlı Tıbbi Etik Proje Yarışmasında sunulmuş olup mansiyon ödülüne layık görülmüştür.

\section{Giriş}

Hastaneye yatan hastaların, hasta hakları çerçevesinde etik bilinçlilikle bakım ve tedavileri yürütülmektedir. Ancak terminal döneme gelindiğinde ve yapılacak bir şey kalmadığı noktasında hastalar çoğu kez eve gönderilmektedir. Bu durumda sağlık profesyonellerin sorumluluğu hastayı eve göndermekle bitiyor mu? Göz görmeyince 
yaşanan ikilemler çözümlenmiş mi oluyor? Tedavi rolümüz rehabilitasyondaki rollerimizin önünde yer aldığından $\mathrm{m} 1$ hastane sonrasındaki yaşanacak durumlar için düşünme eyleminde bulunulmuyor? $\mathrm{Bu}$ bağlamda makalemizde terminal dönem hastalarının yoğun bakım sürecini yaşadıktan sonra yapılacak bir şeyin kalmadığı durumda, insan onuruna yakışır şekilde bakım ve tedavisinin devam edebilmesi ve bu süreci yaşayan hasta ve yakınlarının gereksinimlerinin karşılanabileceği hospislerin Türkiye'de kurulmasının önemi vurgulanmıştır.

Yoğun bakım ünitelerinin standartları genelgesinde yer aldığı üzere yoğun bakım üniteleri bir veya daha fazla organ sistemlerinde ciddi işlev bozukluğu olan kritik hastaları destekleyerek iyileşmesini amaçlayan, ileri teknolojiye sahip cihazlarla donatılmış, hastaların 24 saat yaşamsal göstergelerinin izlendiği, yoğun ve invasif uygulamaların olduğu, hasta tedavi ve bakımının yapıldığı multidisipliner bir ekip ile hizmet sunulan birimlerdir [1].

Yoğun bakım ünitesi hasta kabul-yatış-çıkış kriterleri talimatına göre yoğun bakıma hastaların alınabilmesi için belirlenmiş dört kriter vardır. Bu kriterler [2]:

1. Öncelik: Genel durumları ileri derecede bozulmuş, stabil durumda olmayan, yoğun bakım dişında verilemeyecek ileri düzeyde monitörizasyon ve tedavi gereksinimi olan hastalar (Şok, Septik şok, Hipotansiyon),

2. Öncelik: Hastalıkların seviyesi sırasında acil yoğun tedaviye ihtiyaç duyabilecek ve bu nedenle ağır risk altında olup, ileri monitörizasyon gerektiren hastalar (Renal yetmezlik, kalp, akciğer vs. sistem hastalıkları),

3. Öncelik: Stabil durumda olmayan, önceki sağlık durumları, altta yatan hastalıkları ve hastalıkların tek başına veya kombinasyon nedeni ile iyileşme şans1 ve yoğun bakım tedavisinden yararlanma şans1 çok az olan olgular (Metastatik malignite, End Stage "Son nokta" kalp ve akciğer hastalıkları),

4. Öncelik: Değerlendirme dışı bırakılan hastalar, yoğun bakıma alınması, yoğun bakımda tedavi görmesi uygun görülmeyen hastalar;
a. Bitkisel hayatta olanlar.
b. Geri dönüşümsüz çoklu organ yetmezliği olan hastalar.
c. Kemoterapi, radyoterapiye yanıtsız, metastatik kanserli hastalar.
d. Yoğun bakım desteği, tedavisini reddeden hastalar.
e. Sadece daha iyi bakım sağlanması arzu edilen hastalar.

$\mathrm{Bu}$ önceliklerde görüldüğü üzere yoğun bakıma alınmayan hastalar, "terminal dönemini yaşayan" hastalardır [2]. Buna karşın yoğun bakım ünitelerinde (YBÜ) ekip ve ekipman yetersizliği, sınırlı kaynakların ve hizmetin dağıtılmasıyla ilgili birçok etik problemler yaşanmaktadır [3]. YBÜ'lerde uygulanan tedavi ve bakım sonucunda iyileşme görülmemesi, bütçe ve sağlık çalışanı yetersizliği, YBÜ yatak sayısının azlığı gibi nedenlerle bu ünitelerde triaja gidilmek zorunda kalınmaktadır [4]. Dünya Sağlık Teşkilatı'nın 2009 verilerine göre ülkemizde 10 bin kişiye düşen yatak sayısı 27 civarındayken, bu rakam İngiltere'de 39, Japonya'da 140, Almanya'da 83 ve Fransa'da ise 73 civarındadır [5].

Yoğun bakım ortamların değişken yapısı, ölümle yaşam çizgisinin başlangıcı veya bitişinin belirsizliği nedeniyle; sağlık çalışanlarının yükümlülükleri, bilgilendirilmiş onam alma, resüsitasyon, beyin ölümü, organ transplantasyonu, yaşam desteğini başlatmak ve sürdürmek, sınırlı kaynakların adil dağıtımı, ötanazi ve nafile tedavi (futility) gibi konuların etik sorgulanması çerçevesinde etik ikilemler yoğun bakım ünitelerinde sıkça yaşanmaktadır $[6,7]$. 
Hastanın ya da yakınının tıbbi müdahalenin yararsız ya da eksiksiz olduğu, yaşam kalitesine minumum katkı ya da çok az tıbbi fayda sağladığı, hastanın beklentilerine cevap verme olasılığı taşımadığı ve kabul edilebilir yaşam şansı tanımadığını düşündüğü tedavi ya da uygulamalar futility olarak tanımlanmaktadır [8-10].

"Hastaya uygulanacak olan agresif yaşam destek tedavileri hastaya fizyolojik bir fayda sağlamadığ 1 , hastanın durumunun düzelmesine etkisi olmadığ 1 , aksine fazladan ağrı, acı çekmesine veya bu sıkıntılı sürecin uzamasına neden olduğu durumlarda, tedavinin yapılmaması etik açıdan savunulmaktadır" [8]. Kaynakların etkin ve adil kullanımını sağlamak amaçlı ortaya atılan en önemli etik kriter, tedavinin sağladığı tıbbi yarar ve yaşam kalitesidir [8]. Bu durumda yaşam kalitesi ekonomik kaygı nedeniyle yaşamın niteliğinin, niceliğine göre daha fazla önemsenmesini gündeme getirebileceğinden devlet, adil bir şekilde sağlık kaynaklarından yararlanılmasını sağlamalıdır [11].

Ülkemizde evde bakımla ilgili yönetmelikler ve hospis hizmetiyle dolaylı olarak ilgili yasalar bulunmaktadır. Ancak hospislerin kuruluşları ve işleyişleri hakkında yasal bir düzenleme bulunmamaktadır [12]. Sağlık Bakanlığı tarafından 2001 yılında yayınlanan 'Sağlık Hizmetlerinin Yürütülmesi Hakkında Yönerge' ile sağlık ocakları, kronik ve terminal dönem hastalarının bakım ve tedavisinden sorumlu olarak belirlenmiş olmasına karşın personel yetersizliği, araç-gereç eksikliğinden dolayı yerine getirilememiştir [13]. Oysaki tedavi sürecini tamamlamış veya tedavinin sonuç vermediğinin anlaşıldığı hastaların ve ailelerinin desteklenmesi sürecinde verilen hizmetlerin tamamını kapsayan palyatif bakım önemlidir. Çünkü palyatif bakım, hastanın ve ailenin yaşam kalitesini arttırmayı, ailesinin ve kendisinin hayatı tehdit edici durumlarını engellemeyi, ağrıyı, fiziksel, psikososyal ve spirituel boyuttaki diğer sorunları erken dönemde tanımlamayı, değerlendirmeyi, tedavi etmeyi amaçlayan yaklaşımdır [14].

Dünya Hekimler Birliğince 1981'de yayınlanan Lizbon Bildirgesi ve 1995 tarihli Bali Bildirgeleri ile hastaların acılarının dindirilmesi ve yaşamlarının son döneminde insani bakım alma ve onurlu bir şekilde ölme hakları en temel hasta hakları kapsamında değerlendirilmektedir [15]. Ülkemizde Hasta hakları Yönetmeliğinin 14. Maddesinde hastanın hayatını kurtarmak ve sağlığını korumak mümkün olmadığında acısını azaltmaya veya gidermeye çalışmanın zorunluluğu vurgulanmaktadır [16].

Batı ülkelerinde terminal dönem hastalarının palyatif bakımları için 'hospis' adı verilen kurumlar önemli bir yer tutmaktadır. Terminal dönemdeki hastaların fiziksel semptomlarını gidermek, hasta ile ailesine psikolojik ve sosyal destek sağlamak hospislerin amaçlarındandır. Bilindiği üzere ülkemizde, terminal dönem hastalarını da içinde barındıran huzurevleri ve palyatif tedavi üniteleri dışında hospis bulunmamaktadır [12]. Bu konu dahilinde Aksoy ve ark. [13]'nın bir makalesinde Ankara, İzmir, Şanlıurfa ve Erzurum illerinden seçilen, yarısı sağlık çalışanı, yarısı ise sağlık çalışanı olmayanlar arasından seçilmiş 200 kişiyle terminal dönem ile ilgili sorular içeren bir anket çalışması yapılmıştır. Bu araştırmaya göre sağlık çalışanlarının hastalarını yoğun bakım ünitelerinin stresli ortamından uzaklaştırmak istedikleri, sağlık çalışanı olmayanların terminal dönemdeki hastalarına yapılabilecek bir şeylerin olacağı düşüncesiyle hastalarını son günlerine kadar hastanede tutmaya yöneldikleri belirlenmiştir. Aynı çalışmada her iki gruba hospis kurumuna başvurup-başvurmayacaklarıyla ilgili soruya; sağlık çalışanının $\% 45$, sağlık çalışanı olmayanın \%53 oranında "evet" yanıtını verdiği ifade edilmiştir.

Modern tıp, yaşamı uzatmak için çok etkili yöntemlere sahip olmakla birlikte bu yöntemler ölmekte olan bireylere ağrı ve acı vermektedir. Bununla birlikte Hipokrat yemini gereği insan yaşamının sonuna kadar devam ettirilmesi gerekliliği, hekimin hastasının yaşamını tehdit edici hastalıktan kurtarmasının iş doyumunu artırması, yapılacak olan müdahalelerin ne zaman durdurulacağı konusunda etik ikileme düşürmektedir. Tıp eğitiminde de yaşamın uzatılması, insani acıların azaltılmasından çok daha önemli olduğu vurgulanmaktadır [17]. Oysaki insana özen gösterilmesini Hipokrat yemini işaret etmektedir [18]. Bununla birlikte sağlı çalışanları için ölümün başarısızlık 
olarak algılanması ve YBÜ’lerinin başarısının sağ kalım istatistikleriyle ölçülmesi de bu durumu etkilemektedir. Bunların altındaki asıl neden her şeye rağmen yaşatma güdüsünün ön planda tutulup yaşam kalitesi, maliyet etkinliği, sınırlı kaynakların adil kullanımı gibi kavramların göz ardı edilmesidir [19].

Ciddi hastalıklarla mücadele eden aileler en az hastalar kadar çeşitli sıkıntılar yaşamaktadır [20]. Babaoğlu ve ark. [21], hastalar yeterince anlaşılamadıkları, aile bireylerinden yeterli destek göremedikleri ve iletişimde zorlandıkları için duygusal ve sosyal problemler yaşadıklarını belirtmişlerdir. Yine başka bir araştırmaya göre, kanserin tanı ve tedavi aşamasında hasta ve yakınlarının yaklaşık üçte birinin karşılanmamış gereksinimleri olduğu ve terminal evrede bu oranın \%70'lere kadar yükseldiği görülmüştür [22]. Cimete ve ark. [23]'ın çocuklarını kanser nedeniyle kaybeden aileler üzerinde yaptıkları araştırmasında, ebeveynlerin yarısında somatik hastalıkların geliştiği ifade edilmiştir. Flashkerud ve ark. [24]'nın çalışmasına göre, kanser hastasına bakım veren kişilerin \%70-80'ini eşleri oluşturmaktadır. Hasta yakınları, terminal dönemdeki hastaların gereksinimlerini karşılamanın yanı sıra ailenin diğer üyelerinin günlük yaşamlarını sürdürmelerini sağlayacak sorumlulukları da üstlenmek durumunda kalmaları, onların duygusal ve sosyal sorunlarını artırmaktadır. Bunun sonucunda uzamış bakım, tükenmişlik durumunu da beraberinde getirmektedir. Eşler bu dönemde duygusal alan içinde yalnızlık, korku, ümitsizlik, depresyon, belirsizlik, sosyal alan içinde de çocuk bakımı, ev ile ilgili günlük işler, mesleki ve ekonomik konularda sorunlar yaşamaktadır $[21,25]$. Bu gerekçeyle terminal dönem kanser hastalarına tedavi ve bakımın multidisipliner ekip anlayışı ile verilebileceği, hasta bakımı alırken, eşi dahil olmak üzere sevdikleri ile beraber olabileceği ortamların yaratılmasının hem hasta hem de eş açısından yararlı olacağı düşünülmektedir. Kanser hastaları ve yakınlarının görüşleri üzerine yapılan bir çalışmada da hastaların \%89,4'ü, hasta yakınlarının ise \%97,9'u hospis hizmetlerinin mutlaka olması gerektiğini, olduğu takdirde böyle bir hizmetten yararlanacaklarını ifade etmişlerdir [26]. Terminal dönemdeki kanser hastalarının ölüm yeri tercihlerinin incelendiği bir araştırmada evde ölümler daha fazla tercih edilmişsir [27]. Ancak ölümlerin çoğunluğu hastanede gerçekleşmektedir. Buna bağlı olarak yaşanan sorunlardan birisi de hastaneye yatırılan hasta ve yakını enfeksiyon gibi tıbbi gerekçelerle yaşamın son dönemlerinde birbirleriyle iletişim içinde olmalarının sağlanamamasıdır [25].

Terminal dönem hasta ve yakınlarının gereksinimleri Avrupa ve ABD'de var olan hospislerce karşılanmaktadır [21]. Ötanazinin yasak olduğu ülkemizde de hospis hizmetlerinin sağlanması öncelikli hedefler arasında yer almalıdır. Çünkü ülkemizde hospis bulunmamakta, evde bakım hizmetleri de sinırlı ve özel bakım kurumlarınca yürütülmesi nedeniyle ekonomik değildir [25]. Bu bağlamda hospis tanımı ve tarihçesine değinmek yararlı olacaktır.

\section{Hospisin tanımı}

Latince "hospitium" ve eski Fransızca kelime olan "hospes ya da host" kelimelerinden türemiş olan "Hospice" kelimesi misafirlik anlamına gelmektedir. Sözlüklerde ise kimsesizlerin barındığı ya da yolcuların geçici olarak konakladığı yer olarak tarif edilmektedir. Günümüzde ise bu kelime terminal dönemdeki hastalar ve aileleri için bakım programı olarak tanımlanmaktadır [20, 28]. Hospisler Amerikan yasalarında ise şöyle tanımlanmıştır: "hospis bakımı hastalığının son dönemindeki hastaya geleneksel tedavi ve iyileştirici tedavi yöntemlerinden çok palyatif tedavi verme yaklaşımıyla hareket eden yaşam kalitesinin korunduğu ve semptomların hafifletildiği yerlerdir". Hospis, hastaya ve ailesine destek olarak, hastanın rahat, huzurlu ve onurunu kaybetmeden kaliteli bir hayat standartında son günlerini geçirmesine olanak tanımaktadır. Hospisler disiplinler arası yaklaşım uygulayan, hastaya medikal, sosyal, psikolojik, duygusal ve inanç konularında yardım sağlayan kurumlardır [29]. Hospisler, terminal hastalık yerine, aile ve hastanın duygusal ve fiziksel semptomlarına odaklandığının göstergesi olarak ev ortamına uygun biçimde düzenlenmektedir. Aynı 
zamanda hasta öldükten sonra ailesine yas döneminde destek verir. Kısaca hospisler tedavi edici değil destekleyici ve bakımı bireyselleştirmeye yönelik bir yaklaşım sergilemektedirler [12].

Hospis hizmeti alma ölçütleri Zanes tarafından şöyle belirlenmiştir:

1) Kişilerin şu dört hastalıktan birine sahip olmaları gereklidir;

a) Tedaviye karşın ilerleyen metastatik kanser olguları,

b) AIDS tablosu,

c) Kronik böbrek, karaciğer, kalp ya da akciğer hastalığında sona yaklaşmış olmak,

d) Felcin ilerlemesinin durdurulamadığı sinir sistemi rahatsızlıkları,

2) Ölüme neden olacak böbrek, karaciğer ve kalp yetmezliği gibi durumlar ortaya çıkmalıdır.

3) Birey ve ailesi, hastanın tedavisini yürütmekte olan hekim, hospis bakımda ilkeleri doğrultusunda tedaviye yönelik değil şikayetlerin giderilmesine yönelik uygulamaların yürütüleceğini kabullenmiş olmalıdır [30].

Hospis bakımının fiziksel bakım amaçları içerisinde yer alan acıların dindirilmesi, yaşamın kısaltılması olarak algılanmaktadır. Oysaki bu durumda çift etki prensibi geçerlidir. Çift etki prensibi, "iyi etki elde etmek niyetiyle yapılan bir eylemin önceden bilinen ancak niyetlenilmeyen kötü etkiyi yaratmasıdır". Bu eylem etik açıdan insan öldürmek olarak değerlendirilmemektedir [31]. Burada önemli olan bireyin insan yaşamına ve ölüme ilişkin anlamlandırma biçimidir. Hayat kavramının iki farklı anlamının farkında olunması gereklidir. Bunlardan biri canlı olma, hayatta kalma diğeri insanca yaşamadır. Hospis bakımı kaliteli bir hayatın ve "ölene dek yaşadığının" önemini vurgulamaktadır [28].

\section{Hospislerin ilkeleri}

Hospislerin temel ilkeleri Student'e göre beş maddede toplanmaktadır:

1) Ölümü bekleyen hasta ve yakınlarının gereksinimleri karşılanmaya çalış1lır.

2) Hizmet, disiplinler arası çalışan ekip işbirliği içinde uzman kişilerden oluşmuştur. $\mathrm{Bu}$ ekipte mutlaka hekim, hemşire, hastabakıcı, psikolog, sosyal hizmet uzmanı ve teselli alanında uzmanlaşmış bir din adamı yer alır.

3) Hizmet gönüllü kişilerle birlikte yürütülür. Toplumun temsilcileri olarak bulunurlar ve toplumla iletişimi sağlarlar.

4) Hospis ekibi palyatif bakım konusunda yeterli ve yetkin kişilerdir.

5) Hospislerde kesintisiz 24 saat hizmet esastır. Ölüm sonras1 aileye destek bakımı sağlama sürdürülür [30].

Hospis bakım ekibinin üyeleri hastalarını ve sağlanan bakımı değerlendirmek için düzenli ziyaretlerde bulunurlar. Hospis ekibi hastanın ihtiyaçlarını karşılamak için bakım planları yaparlar ve süregelen durumu tartışmak için disiplinler arası görüşmeleri yönetirler.

Hospis bakımı şunları içermektedir: Hastanın ağrılarını kontrol etmek; hastanın ölüme ilişkin duygusal, psikososyal ve ruhsal endişeleri konusunda ona yardımcı olmak; semptomlara ve konfora ilişkin farmakoterapiyi, medikal desteği ve evde oksijen desteği için gerekli medikal ekipmanları sağlamak; konuşma ve fiziksel terapi; hastanede yatan hastanın ölümü yaklaştığında, evdeki hastanın semptomlarının kontrolü zorlaştığında ya da evdeki bakımı üstlenen kişsinin dinlenmesi gerektiğinde kısa süreli olarak ve hastanın kaybından sonraki bir yıl boyunca aileye matem döneminde yardımcı olmak [28].

Geniş bir yayılımı olmasına rağmen hospis bakımı çok fazla kullanılmamaktadır. Amerika'da, 2007 yılında, 2.4 milyon ölüm olmuş ancak yalnızca \%38'i hospis bakımı 
almıştır. Hospis bakımı alan hastaların servisi kullanma süresi ortalama 20 gün olup, yaklaşık \%31'i yalnızca 7 gün veya daha az bakım almışlardır. Hospis bakımı almaktaki bu gecikme multifaktöriyeldir. Bu faktörler şunları içermektedir;

1) Hekimin hastalığın prognozunun sonuçlarını tahmin etmedeki isteksizlikleri,

2) Hastaların ve hasta yakınlarının terminal hastalığı kabul etmedeki isteksizlikleri,

3) Hospisi ölümü yakın insaların olduğu bir yer olarak düşünmeleri,

4) Irksal/etnik faktörler.

Hastalar ve aileleri hospis bakımını ölümü hızlandırmak ve pes etmek anlamında görmektedirler. Hospis tedaviden çok yaşam kalitesine odaklanmasına rağmen bazı kanıtlar hastaların hospis hizmeti alan hastaların hayatlarının kısalmadığını göstermektedir. Artmış psikososyal desteğin sonucunda, hospis, bazı zamanlar yaşamın süresini uzatabilmektedir [28].

\section{Hospislerin tarihçesi}

Tarihin ilk dönemlerinden beri tedavinin nerede bitmesi gerektiği hep tartış1la gelmiştir. Aesculparius, tedavide limitlerini aştığı ve insanları gereğinden fazla ölümden döndürdügü gerekçesiyle Zeus tarafindan öldürülmüştür. Hipokrat ise hekimlere, hastalarını iyileştiremeyeceği durumlarda tedavi vermeyi reddetmeyi önermiştir [32].

1800'lerden ve endüstrileşme başlamadan önce, insanlar geniş aileler şeklinde yaşamakta ve üretim gücü düşük olan, üretim gücü yüksek olan tarafından dengelenerek aile içinde bir "sosyal dayanışma" oluşturulmaktaydı. Ancak endüstrileşme süreciyle beraber üretim gücü iyi olanlar fabrikalara, daha sonra da bürolara taşınmışlardır. Bunun sonucunda geniş tip ailelerinden ayrılarak ayrı bir ev ve çekirdek aile yapısı oluşmuştur. Bu bölünme sonucunda üretim gücü yüksek olan durmadan çalışmayı seçmiş ve "sosyal yardımlaşmayı" profesyonellere bırakmayı tercih etmişlerdir. Böylece üretim gücü olmayan bireyler profesyonel bakım evlerine gönderilmişlerdir. Tüm bu gelişim süreci kişilerin evlerinden uzakta hastanelerde, bakım evlerinde yalnız başlarına ölmelerine yol açmıştır. Bu davranış tutumu hastaların daha rahat ölebileceği, ölümü beklerken yalnız kalmayacağı ve ilgi göreceği bakım kurumlarının oluşmasına yol açmıştır [33].

Günümüzde hekimlerin ölümü tıbbi ve mesleki başarısızlık olarak görmeleri, zarar vermemek adına hastalarını son dönemde yoğun tedaviye maruz bırakmakta ve hastalarının nerede son günlerini geçirmek istediklerini dikkate almadan onları hastane odalarında tutma eğilimi göstermektedirler. $\mathrm{Bu}$ durum endüstri toplumunda çalışan bireylerin işine gelmiş ve hastalarını son dönemde dahi hastanelere emanet etmişlerdir. $\mathrm{Bu}$ durumlar, hastaların özerkliğine ve ölüm yerini seçme özgürlüğüne aykırı olarak değerlendirildiğinden hospis hareketinin ortaya çıkmasında önemli nedenleri oluşturmuştur [33].

Genel olarak ilk hospisler 11. yy'da haçlılar tarafindan kurulduğu düşünülmektedir. Modern anlamdaki hospislerin ilki 1967 yllında Londra'da Cicely Saunders tarafından St. Christopher's Hospice'ın kurulmasıyla başlamıştır. ABD'de benzer ilk kurum "New Haven Hospice" 1974 yılında açılmıştır. Amerika başkanı Ronald Reagan 1982 yılında, 7-14 Kasım günlerini “Ulusal Hospis Haftası” ilan etmiştir [33]. EAPC'nin (European Association for Palliative Care) 2006 raporlarına göre Almanya'da 331, İngiltere'de 882, Fransa'da 471 tane hospis bulunmaktadır [34]. Günümüzde, hospis bir alan (yer) değil, bir bakım sistemi olarak devam etmektedir. Bakım hastanın evine götürülmekte ya da özel binalarda yapılmaktadır. Hastaların büyük bir çoğunluğu $(\% 70,3)$ hospis bakımını evlerinde almaktadır. Hospis bakımı hastanede yatan hasta için de uygulanabilmektedir [28].

2005 tarihli "Kore Hospis ve Palyatif Bakım Deklarasyonun"da palyatif ve hospis bakımına gereksinimi olan hasta sayısının arttığını, bu doğrultuda hükümetlerin doğru sağlık politikalarının oluşturulması gerektiği, hospis palyatif bakım programlarının kurulması ve geliştirilmesi yönünde ayrıntılı bildirge yayımlamıştır [35]. 
Türkiye'de hospis kavramına yakın ilk kuruluş 1993-1997 yıllarında Türk Onkoloji Vakfı'nın, İstanbul Yeşilköy'deki "Kanser Bakımevi” dir. Ancak bu kuruluş ekonomik nedenlerle ve hospis kavramının yeterince algılanamaması sonucu kapatılmıştır. Daha sonra 2006 yılında tarihi bir Ankara evi, Hacettepe Onkoloji Enstitüsü Vakfı tarafindan palyatif bakım amaçlı hospis açılmıştır. Bu kuruluş ta yasal düzenlemelerin olmayışı nedeni ile "Hacettepe Umut Evi" adı ile kanserli hastaların tedavi ve sonrasında kısa süreli kaldıkları ve hemşire hizmetlerinden yararlanmalarını sağlayacak şekilde hizmet veren bir yere dönüştürülmüştür [12].

\section{Hospislerin örgütlenme biçimleri ve ekonomik boyutu}

Hospisler aşağıdaki dört yoldan birisini seçerek hizmet vermektedirler;

1. Hastaneden bağımsız veya bağlı yataklı kurum şeklinde bununla birlikte eve hizmet götüren bir birim olarak örgütlenmiştir.

2. Yalnızca eve hizmet götüren bir birim olarak örgütlenmiş olabilirler.

3. Danışmanlık görevi şeklinde hizmet verebilirler [30].

Avrupa'da hospisler genellikle giderlerini toplumdan aldıkları bağışlarla karşılamaktadırlar. Yasal düzenlemelerin yapılmış olduğu ülkelerde ise sigortalı hastaların masrafları büyük ölçüde sigortalar tarafından karşılanmaktadır. Hospislerin giderleri büyük oranda bağışlarla sağlandığından hastaların maddi durumlarına bakılmaksızın tüm hastalar hospislere kabul edilmektedir. Ancak bunun sağlanabilmesi için bağışların devamlılı̆̆ 1 ve yasal düzenlemelerle sağlanan devlet desteği önemli rol oynamaktadır [33].

Ayrıca yapılan araştırmalara göre hospislerdeki bakım maliyeti hastanelere oranla daha düşük bulunmuştur. Ohio'da yapılan bir araştırmaya göre hospiste bakım günlük 65USD iken hastanede aynı hastanın bakımı 125USD'yi bulmaktadır. Bu da hospislerde bakımın hastanedeki bakımlara oranla daha ekonomik olduğunu ortaya koymaktadır [33].

Sonuç olarak; hekimlerin karşılaştığı asıl sorunlar yoğun bakım ünitelerinin olanaklarındaki eksiklikler, koşullarındaki olumsuzluklar ve ilişki düzenlerindeki aksamalardır. $\mathrm{Bu}$ sorunlar neticesinde hekimler birçok etik ikilemlerle karşı karşıya kalmaktadırlar. Hasta yakınları cephesinde ise tükenmişlik, hasta cephesinde de onurlu ve rahat bir son dönem geçirme isteği etik ikilemlerin kaynağını oluşturmaktadır. Bu bağlamda yoğun bakım ünitelerinin daha verimli ve amacına uygun çalışabilmesi için yardımcı kurumlarca desteklenmesi gerekmektedir. Batı ülkelerinde hala işlevselliğini sürdüren hospisler yardımcı kurumların en önemli örneklerindendir.

\section{Öneriler}

1. Ülkemizde kişi başına düşen yatak miktarı sınırlıdır. Hastane şartlarını rahatlatmak, hastaların son zamanlarını en iyi şekilde geçirmelerini sağlamak, hasta yakınlarına destek olmak için hospisler açılmalı ve yaygınlaştırılmalıdır. Bunun için dernek, Valilik ve Sağlık Bakanlığı ile işbirliğine gidilmelidir.

2. Hospislerin devamlılı̆̆ının sağlanması için yasalarla güvence altına alınması gereklidir.

3. Bu kurumlara bağış yapılmasını sağlamak için teşvik edici çalışmalar yapılmalıdır.

4. Hospis kavramı hakkında hekim ve sağlık çalışanlarına bu yönde eğitim verilmeli ve akabinde hasta yakınlarına bilgilendirme yapılmalıdır.

5. Palyatif bakım hizmetlerinin sağlık sistemi ile bütünleşebilmesi için gerekli yasal düzenlemelerin yapılması ve ulusal palyatif bakım programlarının hazırlanması için hekim ve sağlık çalışanları konu kapsamında bilinçlendirilmelidir. Var olan Palyatif bakım hizmetleri yaygınlaştırılmalıdır.

6. Hospislerin önemini ortaya koyan çalışmalar çok sınırlıdır. Bu nedenle hospislere yönelik ulusal araştırmalar artırılmalıdır. 


\section{Kaynaklar}

1. Genelge 2008/53. Yoğun bakım ünitelerinin standartlar1: http://www.saglik.gov.tr/TR/dosya/1-38222/h/yogunbakimgenelgesi200853.doc Erişim tarihi: 18.02.2013.

2. http://www.gemlikdh.gov.tr/userfiles/file/HKS\%20Talimatlar/T\%20121\%20Yo\% C4\%9Fun\%20Bak\%C4\%B1m\%20\%C3\%9Cnitesi\%20Hasta\%20Kabul\%20$\% 20$ Yat $\%$ C4\%B1\% $5 \% 9 \mathrm{~F} \% 20-$ $\% 20 \% \mathrm{C} 3 \% 87 \% \mathrm{C} 4 \% \mathrm{~B} 1 \mathrm{k} \% \mathrm{C} 4 \% \mathrm{~B} 1 \% \mathrm{C} 5 \% 9 \mathrm{~F} \% 20$ Kriterleri\%20Talimat\%C4\%B1 \%20Rev02.pdf Erişim tarihi: 18.02.2013.

3. Şahin Gezer D. Yoğun bakım hemşirelerinin yaşadıkları etik sorunlar konusunda Adana ölçeğinde bir araştırma. Yayınlanmamış yüksek lisans tezi. Çukurova Üniversitesi Sağlık Bilimleri Enstitüsü. Tıp Tarihi ve Etik Anabilim Dalı Erişim: library.cu.edu.tr/tezler/7850.pdf. Erişim tarihi: 18.02.2013.

4. Öner Erkekeol F, Numanoğlu N, Ural Gürkan O, Kaya A. Yoğun bakıma ilişkin etik konular. J Toraks 2002; 3: 307-16.

5. World Health Statistics 2009. Health workforce, infrastructure, essential medicines: http://www.who.int/whosis/whostat/EN_WHS09_Table6.pdf. Erişim tarihi: 18.03.2013.

6. Faber-Langendoen K, Lanken PN. Dying patients in the intensive care unit: forgoing treatment, maintaining care. Annals of Internal Medicine 2000; 133: 886-92.

7. Mobley MJ, Rady MY, Verheijde JL, Patel B, Larson JS. The relationship between moral distress and perception of futile care in the critical care unit. Intensive Crit Care Nurs 2007; 23: 256-63.

8. Türk Tabipler Birliği. Yaşamın sonuna ilişkin etik bildirge. Türk Tabipler Birliği Etik Bildirgeleri. Ankara: Türk Tabipler Birliği Yayınları, 2010: 27-30. http://www.ttb.org.tr. Erişim tarihi: 18.02.2013.

9. Cosgrove JF, Nesbitt ID, Bartley C. Futility and the critically ill adult patient: A framework. Current Anaesthesia \& Critical Care 2006; 17: 255-62.

10. Gampel E. Does Professional autonomy protect medical futility judgments? Bioethics 2006; 20: 92-104.

11. Edisan Z, Kadığlu F. Ekonomik ölüm: Etik açıdan eleştirel bir yaklaşım. . 21. Yüzyıl başında yaşama destek tedavileri ve etik hukuksal yönler 2. uluslar arası tıp etiği ve hukuku kongresi kitabı. Ed: Demirhan Erdemir A, Erer S, öncel Ö. Nobel yayıncilik Ankara, 2009; s: 445-51.

12. Bahar A. Ölüm sürecinde olan hasta: Terminal bakım ve hospis. Firat Sağlık Hizmetleri Dergisi 2007; 2: 1-12.

13. Aksoy Ş, Çevik E, Edisan Z. Yaşamın sonunda verilen kararlara ilişkin bir etik çalışma. T Klinikleri Tıp Etiği-Hukuku-Tarihi Derg 2002; 10: 263-8.

14. Algıer L. Çocuklarda palyatif bakım. Ankara Üniversitesi Tıp Fakültesi Mecmuas1 2005; 58: 132-5.

15. Sert G. Hasta hakları-Uluslararası bildirgeler ve tıp etiği çerçevesinde. Babil Yayınları. İstanbul 2004; s: 320.

16. T.C. Sağlık bakanlığı. Hasta Hakları Yönetmeliği. Resmi Gazete, 01.08.1998; Say1: 23420.

17. Namal A. Klinik Rutininde eksik bir boyut: Ölmekte olan hastaya yoldaşlık. 21. Yüzyıl başında yaşama destek tedavileri ve etik hukuksal yönler 2. uluslar arası tıp etiği ve hukuku kongresi kitabı. Ed: Demirhan Erdemir A, Erer S, öncel Ö. Nobel yayıncilık Ankara, 2009; ss: 37.

18. Başar Z. Tarihte ve tıp tarihinde yemin. Atatürk Üniversitesi yayınları No: 218. Sevinç matbaası 1973; s: 77-83.

19. Örnek Büken N. Yaşamın son döneminde hekim-hasta ilişkisi ve etik karar verme süreci. 21. Yüzyıl başında yaşama destek tedavileri ve etik hukuksal yönler 2. uluslar arası tıp etiği ve hukuku kongresi kitabı. Ed: Demirhan Erdemir A, Erer S, 
öncel Ö. Nobel yayıncıllk Ankara, 2009; s: 60.

20. Kökcü AT. Palyatif bakım, Hospisler ve Türkiye'deki durumun değerlendirilmesi. 21. Yüzyıl başında yaşama destek tedavileri ve etik hukuksal yönler 2. uluslar arası tıp etiği ve hukuku kongresi kitabı. Ed: Demirhan Erdemir A, Erer S, öncel Ö. Nobel yayıncılık Ankara, 2009; s: 437-8 .

21. Babaoğlu E, Öz F. Terminal dönem kanser hastasına bakım veren eşlerin duygusal ve sosyal sorunları arasındaki ilişki. Hemşirelik Araştırma Geliştirme Dergisi 2003; 2: 24-33.

22. Shyu YI. Patterns of caregiving when family caregivers face competing needs. J Adv Nurs 2000; 31: 35-43.

23. Cimete G, Kuğuoğlu S. Çocuklarını kanser nedeniyle kaybeden ailelerin, kayıp öncesi ve sonrası yaşadıkları keder süreci. Anadolu Psikiyatri Dergisi 2002; 3: 34-44.

24. Flaskerud JH, Carter PA, Lee P. Distressing emotions in female caregivers of people with AIDS, age-related dementias, and advanced-stage cancers. Perspect Psychiatr Care 2000; 36: 121-30.

25. Oğuz NY, Miles SH, Buken N, Civaner M. End-of-Life Care in Turkey. Camb Q Healthc Ethics 2003; 12: 279-84.

26. Şahin N, Atıcı E, Ülker H. Terminal dönemde bakım: Kanser hastaları ve yakınlarının görüşleri üzerine bir çalışma. 21. Yüzyıl başında yaşama destek tedavileri ve etik hukuksal yönler 2. uluslar arası tıp etiği ve hukuku kongresi kitabı. Ed: Demirhan Erdemir A, Erer S, öncel Ö. Nobel yayıncılık Ankara, 2009; s: 415-26.

27. Işıkhan V. Terminal dönemdeki kanser hastalarının Ölüm yeri tercihleri. Türk Onkoloji Dergisi 2008; 23: 34-44.

28. Lamba S, Quest TE. Hospice care and the emergency department: Rules, regulations, and referrals. Ann Emerg Med 2011; 57: 282-90.

29. Federal Register / Vol. 73, No. 109 / Thursday, June 5, 2008 / Rules and Regulations http://edocket.access.gpo.gov/2008/pdf/08-1305.pdf Erişim tarihi: 18.02.2013.

30. Namal A.Ölümü yaşayabilmek için bir seçenek: hospisler. Ed. Pelin Şahinoğlu S, Arda B, Özçelikay G, Özgür A, Şenler FÇ. III. Tıbbi Etik Sempozyumu Bildirileri. Ankara: Biyoetik Derneği Yayınları; 1998; s: 137-43.

31. Türk Tabipler Birliği. Etik bildirgeler çalıştayı sonuç raporları. Türk Tabipleri Birliği yayınları. Ankara 2008; ss: 33.

32. Lawson AD. Futility. Current Anaesthesia\&Critical Care 2004; 15: 219-3.

33. Namal A. Terminal dönem hastalarına yaklaşıma eleştirel bir bakış ışığında hospis düşüncesi. Demirhan AE, Oğuz Y, Elçioğlu Ö, Doğan H. Klinik Etik. İstanbul: Nobel Tip Kitabevi; 200; s: 595-616.

34. European Association for Palliative Care. Country by country reports. http://www.eapc-taskforce-development.eu/country.php\# Erişim tarihi: 18 Şubat 2013.

35. Elbol Z, Özkul Z. Hospis ve palyatif bakıma dair Mart 2005 Kore bildirgesi. Derleyen Centel N. Hukuk ve etik boyutuyla ötanazi. İstanbul: Koç Üniversitesi Hukuk Fakültesi Disiplinlerarası Hukuk Çalışmaları Serisi No.1; 2011; s: 389-97. 